\title{
TIME-MOTION ANALYSIS OF THE FOOTBALL WORLD CUP IN RUSSIA 2018
}

\author{
Petar Peev $^{1}$, Vasil Tsvetkov ${ }^{1}$, Nestor Youroukov ${ }^{2}$ \\ ${ }^{1}$ National Sports Academy „Vassil Levski”, Sofia, Bulgaria \\ ${ }^{2}$ University of Architecture, Civil engineering and Geodesy, Sofia, Bulgaria
}

\begin{abstract}
The focus of the research is the motion characteristics of the teams which participated in the World cup 2018 in Russia. For the purpose of the research we collected the data from all the matches in the knock out phase of the tournament. We divided the results for every position during the halves and calculated the total distance covered. This way we could get an idea of the intensity and the profile of elite soccer players. In the analyses we included 273 players that played in the knock out phase. As a result of the research, we found that the goalkeeper had total distance covered of 4061,59 meters; defenders had a 9352 meters; midfielders had a 10708 meters and strikers had a 9731 meters. It is interesting that the total distance covered during the second half is greater than in the first one. Conclusion of the research is that the total distance covered is different for all of the researched positions which is a predisposition for disclosing the motor profile of the players. From the study of motor activity in football at world championships we can draw the following conclusions:

1) The results are comfirmation that even at a World Cup the performance characteristics are greatly influenced by position of play;

2) The higher total distance covered during the second half suggests extremely high aerobic capabilities of elite football players.
\end{abstract}

Key words: football, time-motion analysis, motor activity, positional differences

\section{INTRODUCTION}

Over the years, there has been a large number of studies about time-motion analysis in soccer that has always been of interest to sports professionals since the onset of this type of analysis (Bangsbo, 1994; Mohr et al., 2003; Di Salvo et al., 2007; Randers et al., 2007; Rampinini et al., 2009; Harley et al., 2010; Lago et al., 2010; Carling, 2013; Bangsbo, 2014; Goto et al., 2015a; Goto et al., 2015b; Hewitt, 2016). Through time the football game has evolved, which has inevitably led to a change in the motor activity of the players. This is because it is a reflection of the tactical plan of the coach executed by the players on the pitch during the game. Gradually decade after decade, the game has evolved to the point where it is now, and the requirements to the players have also increased. In the very beginning, aerobic capacity and its maximum distance were the most important, but in the last decade the sprint capabilities and the distance covered in the high intensity zones were clearly increasing. The World Cup (WC'18) is considered to be the culmination of the sport performance of the players and as such it is a reference for the motor skills in the development of the football game. It will be interesting to research the characteristics of the motion activity in the world championship. All of this led us to the purpose 
of our research, namely to reveal the trends in motor activity of professional football players at the highest level.

In order to accomplish the aim of the research, we performed the following tasks:

1. Research of the variation of performance characteristics during matches from the elimination phase of World Cup 2018;

2. Comparison of performance characteristics among different positions recorded during the elimination phase of World Cup 2018;

3. Comparison of performance characteristics between halves and zones of intensity observed during the elimination phase of World Cup 2018.

\section{METHODS}

For the fulfillment of the research tasks we used the following methods: observation (time-motion analysis) and statistical procedures (descriptive statistics, Shapiro-Wilk test of homogenityand Independent T-test).

For the purpose of the study, we researched 273 cases of players who participated in a full game from the elimination phase of WC'18 (without extra time). The performance characteristics of these cases was obtained from FIFA official statistics for every match with their different zones of intensity. The zones are as followed: Zone $1-0-7 \mathrm{~km} / \mathrm{h}$; Zone 2 - 7.1-15 km/h; Zone 3 - 15.1-20 km/h; Zone 4 - 20.1-25 km/h; Zone 5 - 25+ km/h. They used for all of the analysis TRACAB optical tracking system (ChyronHego Coorporation, New York, USA). Positional data were collected with Super-HD cameras and patented image processing technology to deliver livetracking of all moving objects with a maximum delay of just three frames. They are located on the main tribune that helps to track the players and the ball. They can be used for real time live foot- age from selected tactical cameras. Also, they use stereo technology to ensure that the entire playing surface is constantly filmed from several angles. All these data are transferered to a cutting-edge software analyses every image to extract $\mathrm{X}, \mathrm{Y}$ and $\mathrm{Z}$ positions for each object resulting in true three-dimensional tracking in real-time. The captured data is processed via an open and versatile protocol allowing it to be made available to any graphics rendering platform. The insights from the technical information and the provided communication link allow for constant real-time interaction that can feed into their decisions during the match. The system has no influence of the weather, lighting and stadia conditions. Also, it is compatable with all the certified wearables and can create Local positioning system (LPS) for even more precise data. Unlike the previous World Cups, five activity zones were used here (Peev, 2017; Gadev and Peev, 2017). We divided the players into four groups, which we borrowed from the statistics obtained - goalkeeper, defender, midfielder and striker. Statistical procedures were performed with SPSS Statistics 19 (IBM, Chicago, Illinois, USA)

\section{RESULTS}

Thirty-two teams took part in the elimination phase, with 16 games played with an average game time of 96:57 minutes. The results of the data processing can be seen in Table 1, 2, 3 and 4 . All the data are presented as an average (Mean result of all cases), maximal and minimal result, standart deviation and coefficien of variation $(\mathrm{CV})$. All of the results are presented in meteres and distance is rounded to the nearest integer.

In Table 1 we can observe the results of the distance covered in different zones and half of 32 goalkeepers that played in the World cup. We can observe CV increases gradually with the increase of the speed. 
Table 1. Variability of performance characteristics of goalkeepers during matches from the elimination phase of World Cup '18

\begin{tabular}{|c|c|c|c|c|c|c|c|c|}
\hline $\begin{array}{c}\text { Indicator } \Rightarrow \\
\text { Statistical } \\
\text { indicator } \sqrt{ }\end{array}$ & $\begin{array}{c}\text { Total } \\
\text { distance } \\
\text { covered }\end{array}$ & $\begin{array}{c}\text { Total } \\
\text { Distance } \\
\text { covered } \\
\mathbf{1}^{\text {st }} \text { half }\end{array}$ & $\begin{array}{c}\text { Total } \\
\text { distance } \\
\text { covered } \\
2^{\text {nd }} \text { half }\end{array}$ & $\begin{array}{c}\text { Zone } \\
0-7 \\
\text { km/h }\end{array}$ & $\begin{array}{c}\text { Zone } \\
7-15 \\
\mathrm{~km} / \mathrm{h}\end{array}$ & $\begin{array}{l}\text { Zone } \\
15-20 \\
\mathrm{~km} / \mathrm{h}\end{array}$ & $\begin{array}{l}\text { Zone } \\
20-25 \\
\mathrm{~km} / \mathrm{h}\end{array}$ & $\begin{array}{c}\text { Zone } \\
25+ \\
\mathrm{km} / \mathrm{h}\end{array}$ \\
\hline Mean & 4062 & 1978 & 2084 & 3200 & 724 & 112 & 22 & 4 \\
\hline Std. Deviation & 790.8 & 398.7 & 413.1 & 483.2 & 306.3 & 64.9 & 16.5 & 8.9 \\
\hline Range & 3147 & 1536 & 1715 & 1911 & 1288 & 300 & 60 & 41 \\
\hline Minimum & 2692 & 1396 & 1296 & 2365 & 225 & 17 & & \\
\hline Maximum & 5839 & 2932 & 3011 & 4276 & 1513 & 317 & 60 & 41 \\
\hline CV\% & 19.5 & 20.2 & 19.8 & 15.1 & 42.3 & 58.1 & 75.3 & 213.4 \\
\hline
\end{tabular}

A total of 118 defenders were researched the goalkeepers. The fact that in the second and their results can be found in Table 2. We half there is greater distance covered than in can observe the same trend here as we did with the first one is interesting.

Table 2. Variability of the performance characteristics of defenders during matches in the elimination phase of World Cup ' 18

\begin{tabular}{|c|c|c|c|c|c|c|c|c|}
\hline $\begin{array}{c}\text { Tested indicator } \Rightarrow \\
\text { Statistical } \\
\text { indicator } \S\end{array}$ & $\begin{array}{c}\text { Total } \\
\text { distance } \\
\text { covered }\end{array}$ & $\begin{array}{c}\text { Total } \\
\text { Distance } \\
\text { covered } \\
1^{\text {st }} \text { half } \\
\end{array}$ & $\begin{array}{c}\text { Total } \\
\text { distance } \\
\text { covered } \\
2^{\text {nd }} \text { half } \\
\end{array}$ & $\begin{array}{c}\text { Zone } \\
\text { 0-7 } \\
\text { km/h }\end{array}$ & $\begin{array}{c}\text { Zone } \\
7-15 \\
\mathrm{~km} / \mathrm{h}\end{array}$ & $\begin{array}{l}\text { Zone } \\
15-20 \\
\mathrm{~km} / \mathrm{h}\end{array}$ & $\begin{array}{l}\text { Zone } \\
20-25 \\
\mathrm{~km} / \mathrm{h}\end{array}$ & $\begin{array}{c}\text { Zone } \\
25+ \\
\mathrm{km} / \mathrm{h}\end{array}$ \\
\hline Mean & 9352 & 4655 & 4697 & 3760 & 3907 & 1086 & 433 & 165 \\
\hline Std. Deviation & 668.6 & 369.9 & 380.4 & 217.4 & 480.7 & 262.7 & 153.7 & 93.4 \\
\hline Minimum & 7944 & 3820 & 3502 & 3314 & 2877 & 593 & 144 & 4 \\
\hline Maximum & 11504 & 5691 & 5813 & 4228 & 5037 & 1857 & 909 & 415 \\
\hline CV\% & 7.2 & 7.9 & 8.1 & 5.8 & 12.3 & 24.2 & 35.5 & 56.5 \\
\hline
\end{tabular}

A total of 78 midfielders played full game in the second half like the defenders. Also, in the elimination phase of the World cup (Ta- they had the greatest total distance covered of ble 3). They had greater total distance covered all the players.

Table 3. Variability of the performance characteristics of midfielders during matches from the elimination phase of World Cup ' 18

\begin{tabular}{|c|c|c|c|c|c|c|c|c|}
\hline Tested indicator $\Rightarrow$ & & & & Zone & & Zone & Zone & Zone \\
\hline $\begin{array}{l}\text { Statistical } \\
\text { indicator } \rrbracket\end{array}$ & $\begin{array}{l}\text { distance } \\
\text { covered }\end{array}$ & $\begin{array}{c}\text { Distance } \\
\text { covered } \\
\mathbf{1}^{\text {st }} \text { half }\end{array}$ & $\begin{array}{l}\text { distance } \\
\text { covered } \\
2^{\text {nd }} \text { half }\end{array}$ & $\begin{array}{c}0-7 \\
\mathrm{~km} / \mathrm{h}\end{array}$ & $\begin{array}{r}7-15 \\
\text { km/h }\end{array}$ & $\begin{array}{l}15-20 \\
\text { km/h }\end{array}$ & $\begin{array}{l}20-25 \\
\mathrm{~km} / \mathrm{h}\end{array}$ & $\begin{array}{c}25+ \\
\mathbf{k m} / \mathbf{h}\end{array}$ \\
\hline Mean & 10708 & 5336 & 5372 & 3621 & 4710 & 1629 & 566 & 182 \\
\hline Std. Deviation & 845.5 & 490.7 & 423.1 & 343.4 & 656.5 & 399.90 & 161.9 & 110.9 \\
\hline Minimum & 9216 & 4402 & 4608 & 2908 & 3469 & 956 & 262 & 11 \\
\hline Maximum & 12435 & 6231 & 6425 & 4539 & 6127 & 2734 & 1085 & 531 \\
\hline CV\% & 7.9 & 9.2 & 7.9 & 9.5 & 13.9 & 24.6 & 28.6 & 60.9 \\
\hline
\end{tabular}

Forty-five strikers were researched in the Also, it is interesting that they had the greatest study (Table 4). Again, in the second half we distance in high-intensity running and sprintcan observe greater total distance covered. ing zone. Another interesting point is that as 
we proceeed from the goalkeepers to the strik- tion as regards the level of preparation is that ers we have smaller and smaller number of of the striker.

players. So maybe the most demanding posi-

Table 4. Variability of the performance characteristics of strikers during matches in the elimination phase of World Cup '18

\begin{tabular}{|c|c|c|c|c|c|c|c|c|}
\hline $\begin{array}{c}\text { Tested indicator } \Rightarrow \\
\text { Statistical } \\
\text { indicator } \sqrt{ }\end{array}$ & $\begin{array}{c}\text { Total } \\
\text { distance } \\
\text { covered }\end{array}$ & $\begin{array}{c}\text { Total } \\
\text { Distance } \\
\text { covered } \\
\mathbf{1}^{\text {st }} \text { half } \\
\end{array}$ & $\begin{array}{c}\text { Total } \\
\text { distance } \\
\text { covered } \\
2^{\text {nd }} \text { half } \\
\end{array}$ & $\begin{array}{c}\text { Zone } \\
0-7 \\
\text { km/h }\end{array}$ & $\begin{array}{c}\text { Zone } \\
7-15 \\
\mathrm{~km} / \mathrm{h}\end{array}$ & $\begin{array}{l}\text { Zone } \\
15-20 \\
\mathrm{~km} / \mathrm{h}\end{array}$ & $\begin{array}{l}\text { Zone } \\
20-25 \\
\mathrm{~km} / \mathrm{h}\end{array}$ & $\begin{array}{c}\text { Zone } \\
25+ \\
\mathbf{k m} / \mathbf{h}\end{array}$ \\
\hline Mean & 9731 & 4859 & 4872 & 3906 & 3770 & 1210 & 591 & 254 \\
\hline Std. Deviation & 786.9 & 473.7 & 405.1 & 233.9 & 638.0 & 243.0 & 127.1 & 110.3 \\
\hline Minimum & 8240 & 3892 & 4056 & 3375 & 2778 & 717 & 356 & 5 \\
\hline Maximum & 11626 & 5836 & 5843 & 4299 & 5029 & 1900 & 1000 & 502 \\
\hline CV\% & 8.1 & 9.8 & 8.3 & 6.0 & 16.9 & 20.1 & 21.5 & 43.4 \\
\hline
\end{tabular}

In order to prove the homogenity of the that for all tested indicators, except for the samples, we used the Shapiro-Wilk coef- third and fifth zone of intensity, the exficient and did the corresponding analy- amined samples have normal distribution sis shown in Table 5. From this we can see $(p>0,05)$.

Table 5. Normality of the distribution of the variables by the Shapiro-Wilk coefficient

\begin{tabular}{|c|c|c|c|c|c|c|c|c|c|c|c|c|}
\hline$\underset{\Rightarrow}{\text { Position }}$ & \multicolumn{3}{|c|}{ Goalkeeper } & \multicolumn{3}{|c|}{ Defender } & \multicolumn{3}{|c|}{ Midfielder } & \multicolumn{3}{|c|}{ Striker } \\
\hline$\underset{\Rightarrow}{\text { Coefficient }}$ & \multicolumn{3}{|c|}{ Shapiro-Wilk } & \multicolumn{3}{|c|}{ Shapiro-Wilk } & \multicolumn{3}{|c|}{ Shapiro-Wilk } & \multicolumn{3}{|c|}{ Shapiro-Wilk } \\
\hline$v^{y^{2}}$ & $\begin{array}{l}\text { Sta- } \\
\text { tistic }\end{array}$ & $\begin{array}{c}\text { Degree } \\
\text { of fre- } \\
\text { edom }\end{array}$ & $\begin{array}{l}\text { Level of } \\
\text { signifi- } \\
\text { cance }\end{array}$ & $\begin{array}{l}\text { Sta- } \\
\text { tistic }\end{array}$ & $\begin{array}{c}\text { Degree } \\
\text { of fre- } \\
\text { edom }\end{array}$ & $\begin{array}{l}\text { Level } \\
\text { of signi- } \\
\text { ficance }\end{array}$ & $\begin{array}{l}\text { Sta- } \\
\text { tistic }\end{array}$ & $\begin{array}{l}\text { Degree } \\
\text { of fre- } \\
\text { edom }\end{array}$ & $\begin{array}{c}\text { Level of } \\
\text { signifi- } \\
\text { cance }\end{array}$ & $\begin{array}{l}\text { Sta- } \\
\text { tistic }\end{array}$ & $\begin{array}{c}\text { Degree } \\
\text { of fre- } \\
\text { edom }\end{array}$ & $\begin{array}{c}\text { Level of } \\
\text { signifi- } \\
\text { cance }\end{array}$ \\
\hline $\begin{array}{l}\text { Total } \\
\text { distance } \\
\text { covered } \\
\text { (m) }\end{array}$ & 0.978 & 32 & 0.724 & 0.985 & 118 & 0.261 & 0.973 & 78 & 0.094 & 0.974 & 45 & 0.442 \\
\hline $\begin{array}{l}\text { Distance } \\
\text { covered } 1^{\text {st }} \\
\text { half }(\mathbf{m})\end{array}$ & 0.950 & 32 & 0.148 & 0.990 & 118 & 0.555 & 0.972 & 78 & 0.082 & 0.978 & 45 & 0.571 \\
\hline $\begin{array}{c}\text { Distance } \\
\text { covered } \\
2^{\text {nd }} \text { half } \\
(\mathrm{m})\end{array}$ & 0.977 & 32 & 0.713 & 0.984 & 118 & 0.216 & 0.971 & 78 & 0.069 & 0.959 & 45 & 0.140 \\
\hline $\begin{array}{c}\text { Zone } \\
0-7 \\
\mathbf{k m} / \mathbf{h}(\mathbf{m})\end{array}$ & 0.973 & 32 & 0.580 & 0.978 & 118 & 0.060 & 0.982 & 78 & 0.331 & 0.972 & 45 & 0.379 \\
\hline $\begin{array}{c}\text { Zone } \\
7-15 \\
\mathrm{~km} / \mathrm{h}(\mathrm{m})\end{array}$ & 0.976 & 32 & 0.672 & 0.989 & 118 & 0.478 & 0.980 & 78 & 0.256 & 0.961 & 45 & 0.159 \\
\hline $\begin{array}{c}\text { Zone } \\
15-20 \\
\mathrm{~km} / \mathrm{h}(\mathbf{m})\end{array}$ & 0.928 & 32 & 0.034 & 0.969 & 118 & 0.159 & 0.972 & 78 & 0.089 & 0.968 & 45 & 0.286 \\
\hline $\begin{array}{c}\text { Zone } \\
20-25 \\
\mathrm{~km} / \mathrm{h}(\mathbf{m})\end{array}$ & 0.949 & 32 & 0.139 & 0.978 & 118 & 0.060 & 0.958 & 78 & 0.052 & 0.963 & 45 & 0.185 \\
\hline $\begin{array}{c}\text { Zone } \\
25+ \\
\mathbf{k m} / \mathbf{h}(\mathbf{m})\end{array}$ & 0.544 & 32 & 0.000 & 0.953 & 118 & 0.201 & 0.906 & 78 & 0,100 & 0.983 & 45 & 0.789 \\
\hline
\end{tabular}


Due to the normal distribution of the vari- Tables 6, 7 and 8. ables, we also have the right to perform a

We can find statistical differences in all the comparative analysis of the results of activity pattern between positions that you can see in researched zone of intensity $(p<0,05)$ of the goalkeepers from all of the other positions.

Table 6. Independence T-test of performance characteristics among defenders and midfielders

\begin{tabular}{|c|c|c|c|c|c|c|c|c|c|c|c|}
\hline \multirow{2}{*}{$\begin{array}{l}\text { Position } \Rightarrow \\
\text { Indicator } \sqrt{ }\end{array}$} & \multicolumn{3}{|c|}{ Defender } & \multicolumn{3}{|c|}{ Midfielder } & \multicolumn{2}{|c|}{ Difference } & \multicolumn{3}{|c|}{$\begin{array}{c}\text { Statistical } \\
\text { Significance }\end{array}$} \\
\hline & $n_{1}$ & $\overline{\mathbf{X}}_{1}$ & $S_{1}$ & $\mathbf{n}_{2}$ & $\mathbf{C}_{2}$ & $\mathbf{S}_{2}$ & d & $d \%$ & $\mathbf{t}_{\text {emp }}$ & $\mathbf{t}_{\mathbf{0 , 0 5}}$ & $\begin{array}{l}\text { Sig.(2- } \\
\text { tailed) }\end{array}$ \\
\hline Total distance covered (m) & 118 & 9352 & 668.6 & 78 & 10708 & 845.5 & 1355.94 & 14.50 & -11.84 & 1.97 & 0.000 \\
\hline $\begin{array}{c}\text { Total distance covered } \\
1^{\text {st }} \text { half }(\mathbf{m})\end{array}$ & 118 & 4655 & 369.9 & 78 & 5336 & 490.7 & 681.12 & 14.63 & -10.39 & 1.97 & 0.000 \\
\hline $\begin{array}{c}\text { Total distance covered } \\
2^{\text {nd }} \text { half }(\mathbf{m})\end{array}$ & 118 & 4697 & 380.4 & 78 & 5372 & 423.1 & 674.82 & 14.37 & -11.51 & 1.97 & 0.000 \\
\hline Zone 0-7 km/h (m) & 118 & 3760 & 217.4 & 78 & 3621 & 343.4 & 139.03 & 3.70 & 3.16 & 1.97 & 0.002 \\
\hline Zone 7-15 km/h (m) & 118 & 3907 & 480.7 & 78 & 4710 & 656.5 & 803.12 & 20.56 & -9.23 & 1.97 & 0.000 \\
\hline Zone $15-20$ km/h (m) & 118 & 1086 & 262.7 & 78 & 1629 & 399.9 & 542.11 & 49.90 & -10.51 & 1.97 & 0.000 \\
\hline Zone $20-25$ km/h (m) & 118 & 433 & 153.7 & 78 & 566 & 161.9 & 132.81 & 30.65 & -5.74 & 1.97 & 0.000 \\
\hline Zone $25+\mathrm{km} / \mathrm{h}(\mathrm{m})$ & 118 & 165 & 93.4 & 78 & 182 & 110.9 & 16.93 & 10.25 & -1.14 & 1.97 & 0.256 \\
\hline
\end{tabular}

From the comparative analysis of motor in all tested parameters except in maximum activity between defenders and midfielders, speeds $(25+\mathrm{km} / \mathrm{h})$. we have statistically significant differences

Table 7. Independence T-test of performance characteristics among defenders and strikers

\begin{tabular}{|c|c|c|c|c|c|c|c|c|c|c|c|}
\hline \multirow{2}{*}{$\begin{array}{l}\text { Position } \Rightarrow \\
\text { Indicator } \sqrt{ }\end{array}$} & \multicolumn{3}{|c|}{ Defender } & \multicolumn{3}{|c|}{ Striker } & \multicolumn{2}{|c|}{ Difference } & \multicolumn{3}{|c|}{$\begin{array}{c}\text { Statistical } \\
\text { Significance }\end{array}$} \\
\hline & $n_{1}$ & $\overline{\mathbf{X}}_{1}$ & $S_{1}$ & $\mathbf{n}_{2}$ & $X_{2}$ & $S_{2}$ & d & $d \%$ & $\mathbf{t}_{\mathrm{emp}}$ & $\mathbf{t}_{0,05}$ & $\begin{array}{l}\text { Sig.(2- } \\
\text { tailed) }\end{array}$ \\
\hline Total distance covered (m) & 118 & 9352 & 668.6 & 45 & 9731 & 787.0 & 379.1 & 4.1 & -2.987 & 1.97 & 0.003 \\
\hline $\begin{array}{c}\text { Total distance covered } \\
1^{\text {st }} \text { half }(\mathbf{m})\end{array}$ & 118 & 4655 & 369.9 & 45 & 4859 & 473.7 & 204.5 & 4.4 & -2.526 & 1.97 & 0.014 \\
\hline $\begin{array}{c}\text { Total distance covered } \\
2^{\text {nd }} \text { half }(\mathbf{m})\end{array}$ & 118 & 4697 & 380.4 & 45 & 4872 & 405.1 & 174.6 & 3.7 & -2.496 & 1.97 & 0.014 \\
\hline Zone 0-7 km/h (m) & 118 & 3760 & 217.4 & 45 & 3906 & 233.9 & 145.4 & 3.9 & -3.625 & 1.97 & 0.000 \\
\hline Zone 7 & 118 & 3907 & 480.7 & 45 & 3770 & 638.0 & 136.7 & 3.5 & 1.262 & 1.97 & 0.212 \\
\hline Zone 15-20 k & 118 & 1086 & 262.7 & 45 & 1210 & 243.0 & 123.5 & 11.4 & -2.652 & 1.97 & 0.009 \\
\hline Zone $20-25$ km/h (m) & 118 & 433 & 153.7 & 45 & 591 & 127.1 & 158.1 & 36.5 & -5.948 & 1.97 & 0.000 \\
\hline Zone $25+\mathrm{km} / \mathrm{h}(\mathrm{m})$ & 118 & 165 & 93.4 & 45 & 254 & 110.3 & 88.8 & 53.8 & -5.003 & 1.97 & 0.000 \\
\hline
\end{tabular}

From the comparative analysis of motor ac- all tested indicators, except for low-intensity tivity between defenders and strikers, we have running $(7-15 \mathrm{~km} / \mathrm{h})$.

a statistically significant difference between 
Table 8. Independence T-test of performance characteristics among midfielders and strike

\begin{tabular}{|c|c|c|c|c|c|c|c|c|c|c|c|}
\hline \multirow{2}{*}{$\begin{array}{l}\text { Position } \Rightarrow \\
\text { Indicator } \sqrt{ }\end{array}$} & \multicolumn{3}{|c|}{ Midfielder } & \multicolumn{3}{|c|}{ Striker } & \multicolumn{2}{|c|}{ Difference } & \multicolumn{3}{|c|}{$\begin{array}{c}\text { Statistical } \\
\text { significance }\end{array}$} \\
\hline & $\mathbf{n}_{1}$ & $\overline{\mathbf{C}}_{1}$ & $\mathrm{~S}_{1}$ & $\mathbf{n}_{2}$ & $\mathbf{X}_{2}$ & $\mathbf{S}_{2}$ & d & $\mathrm{d} \%$ & $\mathbf{t}_{\mathrm{emp}}$ & $\mathbf{t}_{0,05}$ & $\begin{array}{l}\text { Sig. (2- } \\
\text { tailed) }\end{array}$ \\
\hline Total Distance covered (m) & 78 & 10708 & 845.5 & 45 & 9731 & 787.0 & 976.8 & 9.1 & 6.182 & 1.98 & 0.000 \\
\hline $\begin{array}{c}\text { Total distance covered } \\
1^{\text {st }} \text { half }(\mathbf{m})\end{array}$ & 78 & 5336 & 490.7 & 45 & 4859 & 473.7 & 476.6 & 8.9 & 5.136 & 1.98 & 0.000 \\
\hline $\begin{array}{c}\text { Total distance covered } \\
2^{\text {nd }} \text { half }(\mathbf{m})\end{array}$ & 78 & 5372 & 423.1 & 45 & 4872 & 405.1 & 500.2 & 9.3 & 6.268 & 1.98 & 0.000 \\
\hline Zone 0-7 km/h (m) & 78 & 3621 & 343.4 & 45 & 3906 & 233.9 & 284.5 & 7.9 & -5.361 & 1.98 & 0.000 \\
\hline Zone 7-15 km/h (m) & 78 & 4710 & 656.5 & 45 & 3770 & 638.0 & 939.8 & 19.9 & 7.553 & 1.98 & 0.000 \\
\hline Zone $15-20$ km/h (m) & 78 & 1629 & 399.9 & 45 & 1210 & 243.0 & 418.7 & 25.7 & 7.121 & 1.98 & 0.000 \\
\hline Zone $20-25$ km/h (m) & 78 & 566 & 161.9 & 45 & 591 & 127.1 & 25.3 & 4.5 & -.876 & 1.98 & 0.383 \\
\hline Zone $25+\mathrm{km} / \mathrm{h}$ (m) & 78 & 182 & 110.9 & 45 & 254 & 110.3 & 71.9 & 39.5 & -3.394 & 1.98 & 0.001 \\
\hline
\end{tabular}

The comparative analysis of motor activity between midfielders and strikers showed a statistically significant difference between most of the surveyed indicators. The only exception was high-intensity running $(20-25 \mathrm{~km} / \mathrm{h})$.

\section{DISCUSSION}

\section{Total distance covered}

The distance covered can be determined by the total distance covered and the intensity by considering them in individual zones, ranging from low intensive to highly intensity actions. The total distance covered varies between 9-14 km depending on the level of players and their condition (Bangsbo et al., 1994; Mohr et al., 2003; Stølen et al., 2005; Dellal et al., 2010; Gregson et al., 2010; Bojkowski et al., 2015). Most of the distances covered are in low intensity, but the more intense ones are the most important. The distance covered is about 2600-2800 meters for high-intensity actions $(14.8 \mathrm{~km} / \mathrm{h}+)$ and between $200-260$ meters for maximum action or sprinting $(25.2+\mathrm{km} / \mathrm{h})$.

The total distance covered of the goalkeepers $(n=32)$ is lower than previously reported in other similar studies, namely $4062 \mathrm{~m}$. (Di Salvo et al., 2008). However, the distribution of the half distance covered is interesting - the distance covered in the second half is greater than in the first half. Regarding the distribution of the level distance covered by zone, there is nothing that can surprise us. An impressive result is the huge CV of zone 5 (sprinting - 25+ $\mathrm{km} / \mathrm{h}$ ), which is $213.4 \%$. It can be explained by the specific events or pieces of work with maximum intensity, which in most cases is missing with the goalkeepers or is not of such duration to reach over $25 \mathrm{~km} / \mathrm{h}$.

The total of 118 cases of defenders who participated in the matches of the elimination phase of WC' 18 were investigated. The total distance covered is 9352 meters. The distance varies from 7944 to 11504 meters. The coefficient of variation is $7.15 \%$, which determines the sample as homogeneous. However, the range of the maximum and the minimum result is 3560 meters. This difference may be due to defenders' different kind and style of play. The total distance covered during the first and second half shows a similar picture as the total distance covered - it is slightly higher than the distance covered in the first part ( 7.95 and $8.10 \%$ ). In earlier studies, the amount of distance covered is greater in the first part but 
we should mention that no national teams were investigated (Di Salvo et al, 2007; Bradley et al., 2009; Andrzejewski et al, 2012; Bangsbo, 2014; Andrzejewski et al., 2015; Bush et al., 2015; Peev, 2018). Another interesting fact is that the distance covered in the second zone is greater than that in the first zone. From the point of view of the game, this shows its increased dynamics and speed, and hence the need for greater activity of the players. It is normal for the variance in distance covered in the different zones of intensity to increase with the increase in the speed of the running due to the intermittent character of the football game and the tactics and individual capabilities of the players that we see here as well. For defenders we see a small amount of running with a maximum intensity (average 165 meters), which is less than the results so far. A certain fault in this can be attributed to the fact that for the first time there is a zone defined at speeds above $25 \mathrm{~km} / \mathrm{h}$, until now it was $22 \mathrm{~km} / \mathrm{h}$.

Based on the 78 cases of midfielders who played at the WC' 18 shown in Table 3, we can see that the average overtaking distance for the midfielders (10708 meters) varies between 9216 and 12435 meters. The variance of the indicator is $7.9 \%$. The greater results is due to the fact that they are the link in the two phases of the game. The fact is, however, that we observe the same trend for the defenders - increasing the speed of movement also changes the CV from 9.48 to $60.85 \%$. Also, looking at the distance covered halfway through, we see a larger distance covered in the second half than in the first half with 36 meters (5336 vs. 5372 meters). The most likely cause of this trend is the need to solve the match in the second half. The coefficient of variation indicates that on both indicators the aggregate is homogeneous $(\mathrm{CV}=7.88$ and 9.20\%). Looking at the distance covered in the different zones of intensity, we notice a similar trend for the defenders. The largest distance covered is in the second zone, and a relatively low distance covered of running with maximum intensity, but here it is at the expense of higher distance covered values in the middle zone and the high intensity area.

A total of 45 cases of WC' 18 attackers were investigated and the average values can be found in Table 4. From this it can be seen that the average distance covered by the attackers is 9731 meters with individual values ranging from 8240 to 11626 meters and the coefficient of variation $\mathrm{CV}=8.09 \%$ ) pointing to the homogeneous sample. The trend of half distance covered in each half remains the same, with an advantage of the distance covered in the second part of the match (4859 vs. 4872 meters). On the other hand, the strikers do not keep the same trend as the defenders and midfielders. They have greatest distance covered in the first zone. The largest recorded distance covered in the zone of maximum intensity of 254 meters draws one's attention. These two facts together show the specificity of the role of the striker in today's football, namely the slower general movement with sharp inclusions of maximum intensity under appropriate conditions. In other words - their main characteristic is linear velocity and fast accelerations. The attackers show the smallest homogeneity in the high intensity zones $(\mathrm{CV}$ $=21.51$ and $43.44 \%$ ).

In spite of the homogeneity of the sample, a number of conditions associated with various factors during a football match such as hosting, match development, enemy level influence the time-motion (Lago et al., 2010). According to Lago et al. (2010) when playing against a stronger opponent, the overall distance is 15 meters more per match depending 
on the difference with the opponent's ranking. These tests, however, have been made in the championships in Europe which have a different format and are not fully applicable in our case. As can be seen from all surveyed groups with increasing speed, the coefficient of variation, which is due to the needs of the game, increases. There is almost no information about national teams and motor activity.

Interesting is the fact that no matter of the position on the field during the second half the total distance is greater than the distance in the first one. This is in contradiction with the current understanding and research in football. The reduction of the distance covered is contrary to the data of other authors investigating motor activity of both men and adolescents (Bangsbo et al., 1994; Mohr et al., 2003; Barros et al., 2007; Di Salvo et al., 2007, Bradley et al., 2009, Rampinini et al., 2007; Rampinini et al., 2009; Dupont et al., 2010; Carling and Dupont, 2011). Although statistically significant in scientific circles, there is a controversy about whether this difference within 90 minutes matters for the end result (Carling, 2013). From the data in some studies we can observe a decrease in the total distance between the first and second half between 2-7\% (Mohr et al., 2003; Bradley et al., 2009; Dupont et al., 2010; Carling et al., 2011). In our study there is no decrease but an increase of the average of 0.26 to $5.26 \%$ for the different positions, which is imposed by the need to solve the match. Also, under the influence of the tactical concept and the specific needs of the tournament, it can be assumed that there is some storage and saving of power during the first half of the WC'18. Studies by Casamichana and Castellano (2014) and Lago et al. (2010) support this thesis no matter that they are completely opposite in their statements.

\section{Distance covered among different zones}

Current studies of motor activity by zones in male footballers are missing, except for a few (Gregson et al., 2010; Dellal et al., 2011; Bojkowski et al., 2015; Chmura et al., 2017). According to Dupont et al. (2010) there is a big difference between the coefficient of variation in the individual Sprint and Running with high intensity. This may be due to the ability of the investigated person to behave to the maximum speed, the strength of the opponent, or the tactical intention of the coach (Gregson et al., 2010).

A big part of the results from the research is unique and there is no information about distance covered, but this is understandable due to the large number of different methods for determining the mobility zones and hence for the zones themselves (Peev, 2017; Gadev and Peev, 2017). Table 9 shows some of the activity zones of professional football players in the world. There are certain similarities, but also differences between the characteristics. The most pronounced differences are between low-intensity actions, the distance covered of which is considerably lower for competitors participating in $\mathrm{WC}^{6} 18$ regardless of post. The total distance covered differs within certain limits, but given that in our case they are divided into groups and in the other studies they are considered in general, so we can not draw definite conclusions. Table 9 shows the different categories in the studies made. All the data are based on semiautomatic and automatic video-based method of data capturing. 
Table 9. Distance covered among different zones of intensity of major chanmpionships

\begin{tabular}{|c|c|c|c|c|c|c|c|c|}
\hline Tested & Author & Year & $\begin{array}{c}\text { Total } \\
\text { Distance } \\
\text { (m) }\end{array}$ & $\begin{array}{c}\text { Total } \\
\text { distance } \\
\text { covered } \\
\text { in } \\
\text { walking } \\
(\mathrm{m})\end{array}$ & $\begin{array}{c}\text { Total dis- } \\
\text { tance } \\
\text { covered } \\
\text { in low } \\
\text { intensity } \\
\text { running } \\
\text { (m) }\end{array}$ & $\begin{array}{l}\text { Total dis- } \\
\text { tance co- } \\
\text { vered in } \\
\text { medium } \\
\text { intensity } \\
\text { running } \\
\text { (m) }\end{array}$ & $\begin{array}{l}\text { Total dis- } \\
\text { tance co- } \\
\text { vered in } \\
\text { intensity } \\
\text { running } \\
\text { (m) }\end{array}$ & $\begin{array}{c}\text { Total } \\
\text { distance } \\
\text { covered in } \\
\text { maximal } \\
\text { intensity } \\
\text { running/ } \\
\text { sprinting } \\
(\mathrm{m})\end{array}$ \\
\hline Goalkeepers & Peev et al. & 2019 & 4062 & 3200 & 724 & 11,8 & 22 & 4,2 \\
\hline Defenders & Peev et al. & 2019 & 9352 & 3760 & 3907 & 1086 & 433 & 165 \\
\hline Midfielders & Peev et al. & 2019 & 10708 & $\begin{array}{l}3621 \\
3906\end{array}$ & $\begin{array}{l}4710 \\
3770\end{array}$ & $\begin{array}{l}1629 \\
1210\end{array}$ & $\begin{array}{l}566 \\
591\end{array}$ & $\begin{array}{l}182 \\
254\end{array}$ \\
\hline Strikers & Peev et al. & 2019 & 9731 & $0-7 \mathrm{~km} / \mathrm{h}$ & $7.1-15 \mathrm{~km} / \mathrm{h}$ & $\begin{array}{c}15.1-20 \\
\mathrm{~km} / \mathrm{h}\end{array}$ & $\begin{array}{c}20.1-25 \\
\mathrm{~m} / \mathrm{h}\end{array}$ & $25+\mathrm{km} / \mathrm{h}$ \\
\hline Bulgaria & Peev & 2017 & 10607 & $\begin{array}{c}6341 \\
0-7 \mathrm{~km} / \mathrm{h}\end{array}$ & $\begin{array}{c}1870 \\
7.1-15 \mathrm{~km} / \mathrm{h}\end{array}$ & $\begin{array}{c}1615 \\
15.1-20 \\
\mathrm{~km} / \mathrm{h}\end{array}$ & $\begin{array}{c}523 \\
20.1-25 \\
\mathrm{~m} / \mathrm{h}\end{array}$ & $\begin{array}{c}259 \\
25+\mathrm{km} / \mathrm{h}\end{array}$ \\
\hline Premiership & $\begin{array}{l}\text { Bush } \\
\text { et al. }\end{array}$ & 2015 & 10659 & & & & & \\
\hline Spain & $\begin{array}{l}\text { Di Salvo } \\
\text { et al. }\end{array}$ & 2007 & $\begin{array}{l}11393 \\
0-0,6 \\
\mathrm{~km} / \mathrm{h}\end{array}$ & $\begin{array}{l}7080 \\
0.6-7 \\
\mathrm{~km} / \mathrm{h}\end{array}$ & $\begin{array}{c}1380 \\
7.2-14.3 \\
\mathrm{~km} / \mathrm{h}\end{array}$ & $\begin{array}{c}1257 \\
14.4-19.7 \\
\mathrm{~km} / \mathrm{h}\end{array}$ & $\begin{array}{c}397 \\
19.8-25.1 \\
\mathrm{~m} / \mathrm{h}\end{array}$ & $\begin{array}{c}215 \\
25.2+ \\
\mathrm{km} / \mathrm{h}\end{array}$ \\
\hline Brasil & $\begin{array}{l}\text { Barros } \\
\text { et al. }\end{array}$ & 2007 & 10642 & $\begin{array}{c}5537 \\
0-11 \\
\mathrm{~km} / \mathrm{h}\end{array}$ & $\begin{array}{c}1731 \\
11.1-14 \\
\mathrm{~km} / \mathrm{h}\end{array}$ & $\begin{array}{c}1615 \\
14.1-19 \\
\mathrm{~km} / \mathrm{h}\end{array}$ & $\begin{array}{c}691 \\
19.1-23 \\
\mathrm{~m} / \mathrm{h}\end{array}$ & $\begin{array}{c}437 \\
23.1+ \\
\mathrm{km} / \mathrm{h}\end{array}$ \\
\hline Denmark & $\begin{array}{l}\text { Randers } \\
\text { et al. }\end{array}$ & 2004 & 10800 & & & & & \\
\hline FC Barcelona & $\begin{array}{l}\text { Zubillaga } \\
\text { et al. }\end{array}$ & 2002 & 10339 & 6871 & 1293 & \multicolumn{2}{|c|}{1716} & 470 \\
\hline FC Arsenal & $\begin{array}{l}\text { Zubillaga } \\
\text { et al. }\end{array}$ & 2002 & 10549 & $\begin{array}{c}7159 \\
0-11 \\
\mathrm{~km} / \mathrm{h}\end{array}$ & $\begin{array}{c}1329 \\
11.1-14 \\
\mathrm{~km} / \mathrm{h}\end{array}$ & \multicolumn{2}{|c|}{$14.1-21 \mathrm{~km} / \mathrm{h}$} & $\begin{array}{c}410 \\
21+\mathrm{km} / \mathrm{h}\end{array}$ \\
\hline
\end{tabular}

Distance covered in high-intensity and sprinting

In recent years, however, there has been a tendency of reduction the absolute values of the distance covered at the expense of intensification. The total distance covered is reduced, but the average speed and maximum speeds are increased (Bush et al., 2015). This may be due to the results achieved by Castellano et al. (2014), which indicate a lack of statistical reliability of the distance covered between players at different levels. According to the authors, the highly intensive actions that depend on the anaerobic energy system are those that separate the successful teams from the others (Mohr et al., 2003; Rampinini et al., 2009; Bangsbo, 2014; Broich et al., 2014; Chmura et al., 2017). Other authors, such as Green (1992), Tumilty (1993), disagree with this view, but their research was made at a time when football did not have such demands on the preparation of the player. In tactical terms, this is reflected in the absence of large empty spaces between players' lines and in their own half in defensive play, and in the foreground the maximum speeds and the ability to show speed. In fact, according to Bush et al. (2015) the Premier League sprints have increased by $50 \%$ over the past 10 years.

\section{Positional differences}

The midfielders have the greatest distance covered of motor mobility of all the other players (Mohr et al., 2003; O`Donoghue et 
al., 2005; Rampinini et al., 2007; Vigne et al., 2010; Dellal et al., 2011; Andrzejewski et al., 2015; Andrzejewski et al., 2016). An exception to this rule was presented in the study of Carling (2013). On the second place are the strikers, followed by the defenders and the goalkeepers are with the lowest distance covered of motor activity.

The smallest distance covered of motor activity is achieved by the defenders, this is predetermined by their role in the team - to give stability and to build the attack of the team. Most of their activity is of low intensity, quite opposite to midfielders.

On the other hand, we would also like to note that despite the observed differences (not always statistically supported) in the activity of individual posts (Di Salvo et al., 2007; Buchheit et al. 2008; Bradley et al., 2009), we believe it is wrong for a collective game to go to individualizing the workload in positions, and it is right for the players to prepare for each of the types of motor activity. Some authors go further by placing individual load zones for each competitor (Abbott et al., 2018)

In this respect, we support the opinion of Abt and Lovell (2009) and Siegel and Lames (2010) expressing the need to use individualised activity zones for individual age groups and, at the same time, the need for individual work zones for each competitor.

High-intensity running and sprinting distances are a widely-studied problem because of their importance in football. However, these studies do not give a clear indication of the average distance covered of maximum intensity due to different measuring instruments and zones of intensity, as well as the constant division of the players into an increasing number of individual categories. Also, for the most part, the sprint distance and high-intensity running depend on the level of the players, the championship and their play- ing position (Dellal et al., 2010; Andrzejewski et al. 2015). They are the greatest for the strikers because as the authors point out they are dependent on the position on the pitch and the strikers are characterized with sharpness and the ability to develop linear velocity (Dellal et al., 2011; Andrzejewski et al., 2015). This is due to strikers'need to transfer as fast as they can for the attack and conquer the free space and suprise the opposite team. Similar research in the League of Europe, with a sprinting speed of $24 \mathrm{~km} / \mathrm{h}$, shows an average of $237 \pm 123$ meters of distance covered, coinciding with Dellal et al. (2010) and Dellal et al. (2011).

The smallest sprint and high-intensity distance covered are shown by the defenders (Dellal et al., 2011 Andrzejewski et al., 2015), which is largely related to their positional play. Findings of Bush et al. (2015) support our results. They have found the greatest increase in these characteristics among full backs followed by central defenders in last years. It must be noted that these differences observed among the individual players' positions are a direct consequence of the tactics and the role of the individual units in the team.

Midfielders perform a relatively large distance covered of work in high-intensity work zones, but because they work in zones where there are not so many free spaces. Their sprinting activity is limited and determined by the specificity of their position of play i.e. participation in attacks and defence.

It is intresting that defenders (players that have the smallest amount of sprint) face the players with the greatest volume of sprints the strikers. This should be a topic for future studies, and it can be taken into account in selection of young players.

As a general constation, we can confirm that the total distance covered doesn't differ from the one described in the literature. Suprisingly 
the second zone $(7-15 \mathrm{~km} / \mathrm{h})$ is the one with the greater distance for defenders and midfielders. There aren't changes in performance characteristics except for the strikers for these zones. Strikers have the greatest amount of sprinting activity. Normally the highest amount of running distance and high-intensity running are characteristic of midfielders.

\section{CONCLUSION}

The studied performance characteristics in football at world championships are the first available data of that kind. Until now no one has ever presented result of performance characteristics in five zones of intensity.

1. The results are comfirmation that even at a

World Cup the performance characteristics are greatly influenced by position of play;

2. The higher total distance covered during the second half suggests extremely high aerobic capabilities of elite football players.

\section{PRACTICAL APPLICATION}

The results obtained could help the selection of the young football players. The presented results can help conditioning coaches to optimize the training load throughout the pre-season and season preparations.

\section{REFERENCES}

Abbott, W., Brickley, G. and Smeeton, N.J. (2018). Physical demands of playing position within English Premier League academy soccer. Journal of Human Sport and Exercise, Vol. 13, No. 2, pp. 285-295.

Abt, G. and Lovell, R. (2009). The use of individualized speed and intensity thresholds for determining the distance run at high-intensity in professional soccer, Journal of Sports Sciences, July; Vol. 27, No. 9, pp. 893-898.

Andrzejewski, M., Chmura, J., Pluta, B. and Kasprzak, A. (2012). Analysis of motor activities of professional soccer players. The
Journal of Strength \& Conditioning Research, Vol. 26, No. 6, pp. 1481-1488.

Andrzejewski, M., Chmura, J., Pluta, B. and Konarski, J. M. (2015). Sprinting activities and distance covered by top level Europa League Soccer Players. International Journal of Sports Science \& Co-aching, Vol. 10, No. 1, pp. 39-50.

Andrzejewski, M., Chmura, J., Pluta, B., Strzelczyk, R. and Kasprzak, A. (2013). Analysis of sprinting activities of professional soccer players, Journal of Strength and Conditioning Research, , Vol. 27, No. 8, pp. 2134-40.

Bangsbo, J. (1994). The physiology of soccer: with special reference to intense intermittent exercise, In Acta Physiol Scand,(Print Edition), Supplementum, Vol. 15, No. 619, pp. 1-156.

Bangsbo, J. (2014). Physiological demands of football, Sports Science Exchange, Vol. 27, No. 125, pp. 1-6

Barros, R.M.L., Misuta, M.S., Menezes, R.P., Figueroa, P.J., Moura, F.A., Cunha, S.A., Anido, R. and Leite, N.J. (2007). Analysis of the Distances Covered by First Division Brazilian Soccer Players Obtained with an Automatic Tracking Method, Journal of Sports Science and Medicine, Jun, Vol. 6, No. 2, pp. 233-242.

Bojkowski, Ł., Śliwowski, R., Wieczorek, A. and Eider, J. (2015). Analysis of the longest distances run by the best soccer players at the FIFA World Cup in Brazil in 2014, Central European Journal of Sport Sciences and Medicine, Vol. 27, No. 2, pp. 145-151.

Bradley P.S., Sheldon, W., Wooster, B., Olsen, P., Boanas, P. and Krustrup, P. (2009). Highintensity running in English FA Premier League soccer matches. Journal of sports sciences, Jan 15, Vol. 13, No. 2, pp. 159-68.

Broich, H., Mester, J., Seifriz, F., and Zengyuan, Y.U.E. (2014). Statistical analysis for the First Bundesliga in the current soccer sea- 
son. Progress in Applied Mathematics, Vol. 7, No. 2, pp. 1-8.

Buchheit, M., Delhomel, G. and Ahmaidi, S. (2008). Time-motion analysis of elite young French soccer players. Coach Sport Sci J, Vol. 3, No. 2, pp. 21.

Bush, M., Barnes, C., Archer, D.T., Hogg, B.and Bradley, P.S. (2015). Evolution of match performance parameters for various playing positions in the English Premier League, $\mathrm{Hu}$ man Movement Science, Vol. 39, pp. 1-11.

Carling, C. (2013). Interpreting physical performance in professional soccer matchplay: Should we be more pragmatic in our approach?, Sports Medicine, August, Vol. 43, No. 8, pp. 655-63.

Carling, C. and Dupont, G. (2011). Are declines in physical performance associated with a reduction in skill-related performance during professional soccer match-play?, Journal of sports sciences. Jan, Vol. 29, No. 1, pp. 6371

Casamichana, D. and Castellano, J. (2014). Situational variables and distance covered during the fifa wold cup south africa 2010, Revista Internacional de Medicina y Ciencias de la Actividad Física y del Deporte, , Vol. 14, No. 56, pp. 603-617.

Castellano, J., Blanco-Villasenor, A. and Alvarez, D. (2011). Contextual variables and time-motion analysis in soccer, International Journal of Sports Medicine, Jun, Vol. 32, No. 6, pp. 415-21.

Castellano. J., Alvarez-Pastor, D., and Bradley, P.S. (2014). Evaluation of research using computerized tracking systems (Amisco and Prozone) to analyse physical performance in elite soccer: A systematic review, Sports Med, 44, pp. 701-712.

Chmura, P., Andrzejewski, M., Konefał, M., Mroczek, D., Rokita, A. and Chmura, J. (2017). Analysis of motor activities of professional soccer players during the 2014 World
Cup in Brazil. Journal of Human Kinetics, Vol. 56, No. 1, 187-195.

Dellal, A., Chamari, K., Wong, D. P., Ahmaidi, S., Keller, D., Barros, R., Bisciotti, G.N. and Carling, C. (2011). Comparison of physical and technical performance in European soccer match-play: FA Premier League and La Liga, European Journal of Sport Science, Vol. 11, No. 1, pp. 51-59.

Dellal, A., Wong, D. P., Moalla, W. and Chamari, K. (2010). Physical and technical activity of soccer players in the French First League-with special reference to their playing position. International SportMed Journal, Vol. 11, No. 2, pp. 278-290.

Di Salvo, V., Baron, R, Tschan, H., Calderon Montero, F.J., Bachl, N. and Pigozzi, F. (2007). Performance characteristics according to playing position in elite soccer, International Journal of Sports Medicine, Vol. 28, No. 3, pp. 222-227.

Di Salvo, V., Benito, P. J., Calderon, F. J., Di Salvo, M., and Pigozzi, F. (2008). Activity profile of elite goalkeepers during football match-play, Journal of Sports Medicine and Physical Fitness, The, Vol. 48, No.4, pp. 443.

Di Salvo, V., Pigozzi, F., González-Haro, C., Laughlin, M.S. and De Witt, J.K. (2013). Sprinting analysis of elite soccer players during European Champions League and UEFA Cup matches, Journal of sports sciences, Vol. 28, No. 14, pp. 1489-1494.

Dupont, G., Nedelec, M., McCall, A., McCormack, D., Berthoin, S. and Wisloff, U. (2010), Effect of 2 soccer matches in a week on physical performance and injury rate. The American Journal of Sports Medicine, Sep;38(9):1752-8.

Gadev, M. and Peev, P. (2017). Motor activity speed zones determination with football players aged 13-14, Research in Kinesiology, Vol. 45, No. 1, pp. 21-24.

Goto, H., Morris, J.G. and Nevill, M.E. 
(2015a). Motion analysis of U11 to U16 elite English Premier League academy Players, Journal of Sports Sciences, June, Vol. 33, No. 12, pp. 1248-1258

Goto, H., Morris, J.G. and Nevill, M.E. (2015b). Match Analysis of U 9 and U 10 English Premier League academy soccer Players using a Global Positioning System, Journal of strength and conditioning research, April, Vol. 29, No. 4, pp. 954-63.

Green, S. (1995). Measurement of anaerobic work capacities in humans, Sports Medicine, Vol. 19, No. 1, pp. 32-42.

Harley, J. A., Barnes, C.A., Portas, M., Lovell, R., Barrett, S., Paul, D. and Weston, M. (2010). Motion analysis of match-play in elite U12 to U16 age-group soccer players, Journal of Sports Sciences, Nov, Vol. 28, No. 13, pp. 1391-1397.

Hewitt, A. (2016). Performance Analysis in Soccer: Applications of Player Tracking, Canberra, Australia, Ph.D. thesis, pp. 181.

Kjøsnes, T.N. (2014). The development of physical performance during elite soccer matches-can motion analysis contribute to identify fatigued footballers?. Masters thesis. Norges teknisk-naturvitenskapelige universitet, Det medisinske fakultet, Institutt for sirkulasjon og bildediagnostikk, Trondheim, Norway, pp. 34.

Lago, C., Casais, L., Dominguez, E. and Sampaio, J. (2010), The effects of situational variables on distance covered at various speeds in elite soccer, European Journal of Sport Science, March, Vol. 10, No. 2, pp. 103-109

Mohr, M., Krustrup, P. and Bangsbo J. (2003). Match performance of high-standard soccer players with special reference to development of fatigue, Journal of sports sciences, Jul, Vol. 21, No. 7, pp. 519-28

Odetoyinbo, K., Wooster, B. and Lane, A. (2009). The effect of a succession of matches on the activity profiles of profes- sional soccer players. In T. Reilly \& F. Korkusuz (Eds.), Science and Football VI: Proceedings of the sixth world congress on football, London: Routledge, pp. 105-110.

O‘Donoghue, P., Rudkin, S., Bloomfield, J., Powell, S., Cairns, G., Dunkerley, A., Davey, P., Probert, G. and Bowater, J. (2005). Repeated work activity in English FA Premier League soccer, Journal of Performance Analysis in Sport, Vol. 5, No. 2, pp. 46-57.

Peev, P. (2017). Metodicheski podhodi za vuzdeistvie varhu skorostnata izdrajlivost pri 13-14 godishni futbolisti, Sofia, PhD thesis, pp.167 // Пеев, П., (2017). Методически подходи за въздействие върху скоростна издръжливост при13-14 годишни футболисти, София, докторат, с. 167.

Peev, P. (2018). Analiz na dvigatelnata mobilnost pri visokokvalificirani, Leka atletika $i$ nauka, Vol. 1, No. 18, (predpechat) // Пеев, П. (2018). Анализ на двигателната мобилност при висококвалифицирани футболисти, Лека атлетика и наука (предпечат).

Rampinini, E., Impellizzeri, F.M., Castagna, C., Coutts, A.J. and Wisloff, U. (2009) Technical performance during soccer matches of the Italian Serie A league: Effect of fatigue and competitive level, Journal of Science and Medicne in Sport, Vol. 12, pp. 227-233.

Rampinini, E., Coutts, A.J., Castagna, C., Sassi, R. and Impellizzeri, F.M. (2007). Variation in Top Level Soccer Match Performance, International Journal of Sports Medicine, Dec, Vol. 28, No. 12, pp. 1018-1024.

Randers, M.G., Jensen, J.M. and Krustrup, P. (2007). Comparison of activity profile during matches in Danish and Swedish premier league and matches in Nordic royal league tournament, Journal of Sports Science and Medicine, Vol.6, No. 10, pp. 16.

Siegle, M. and Lames, M. (2010). The relation between movement velocity and movement pattern in elite soccer, International 
Journal of Performance Analysis of Sport, Journal of Sports Medicine, Vol. 31, No. 5, pp. Vol. 10, No. 3, pp. 270-278 304-310.

Tumilty, D. (1993). Physiological characteristics of elite soccer players, Sports Medicine, Aug, Vol. 16, No. 2, pp. 80-96.

Zubillaga, A., G. Gorospe, A. H. Mendo, A. B. Villaseñor (2007). Match analysis of 2005-06 champions league final with Amis-

Vigne, G., Gaudino, C., Rogowski, I., Alloatti, G. and Hautier, C. (2010). Activity proco system, Journal of Sports and Science file in elite Italian soccer team. International Medicine,Vol. 6, No. 10, pp. 20

\section{Corresponding author:}

Petar Peev

Track and field athletics department National Sports Academy „Vassil Levski” Studentski grad, 21, Acad. Stefan Mladenov str. Sofia 1700, Bulgaria E-mail: petar.r.peev@gmail.com 